\title{
The Probe into the Multi-dimensional Interaction Model in College English Teaching
}

\author{
Mei Zhang \\ Basic Courses Teaching Department \\ The Armed Police Academy \\ Langfang, Hebei, China, 065000 \\ e-mail: 705145319@qq.com
}

\begin{abstract}
The multi-dimensional interaction English teaching is a new teaching model. This model can improve learners' language knowledge and skills, and develop their abilities to learn independently and cooperatively. The paper mainly elaborates the concept and classification of multi-dimensional interaction teaching model as well as theoretical basis, teaching objectives, realizing conditions and teaching strategies.
\end{abstract}

Keywords-multi-dimensional interaction; theoretical basis; teaching objectives; realizing conditions; teaching strategies

\section{INTRODUCTION}

The Ministry of Education launched the "College English Curriculum Requirements" (Requirements hereafter) in 2007. The "Requirements" emphasizes the objective of College English is to develop students' ability to use English in an all-round way, especially in listening and speaking, so that in their future work and social interactions they will be able to exchange information effectively through both spoken and written channels, and at the same time they will be able to enhance their ability to study independently and improve their cultural quality so as to meet the needs of China's reform, social development and international exchanges. The new teaching goal requires a corresponding teaching philosophy and specific implementation model. The change in teaching model by no means caters for a shift from the traditional teacher-centered pattern to the student-centered pattern, which focuses on the multi-dimensional interaction among various elements associated with teaching process.

\section{THE DEFINITION AND ClASSIFICATION OF MulTi-DiMENSIONAL ENGLISH TEACHING}

The interaction is a word derived from the field of social psychology. It can be defined as a collaborative exchange of thoughts, feelings, or ideas between two or more people resulting in a reciprocal effect on each other. Later, the interaction has been introduced into the field of teaching. The interaction in teaching refers to the interaction among the various elements associated with the teaching process. This interaction is multi-dimensional. The nature of the multi-dimensional interaction teaching is to provide students with as many opportunities as possible to practice the language to improve students' language proficiency.
The multi-dimensional teaching is divided into "teacher — student(s)" pattern, "student(s)—student(s)"pattern, "student(s) - teaching media" pattern and "teaching media-teaching media" pattern. The "teacher-student(s)" pattern and the "student(s) - student(s)" pattern are the basic forms of interaction teaching. The teaching media involves textbooks, teaching methods, teaching objectives, teaching contents, Etc.

\section{THEORETICAL BASIS FOR THE MULTI-DIMENSIONAL INTERACTION ENGLISH TEACHING}

\section{A. Constructivist theory}

According to constructivism, students build up their own knowledge structure in the process of their learning rather than obtaining knowledge directly from the teacher. In another word, the students do not learn what the teacher teaches in the classroom word by word, but learn the knowledge with the help of their own experience and understanding. From this point of view, the students are not the passive receivers or containers of the knowledge but the active builders of constructing their own knowledge structure, a reform should be implemented on the traditional teacher-centered method. The role of teachers is very important within the constructivism learning theory. Instead of giving a lecture the teachers in this theory function as facilitators whose role is to aid the student when it comes to their own understanding.

\section{B. Social interaction theory}

Social interaction theory emphasizes interactive social environment, as well as the interaction among teachers, learners and activities. In this theory, children are born into a social world and learning occurs through the interaction with other people. It stresses not only the cognitive process

From the time we are born we interact with others in our day-to-day lives, and through these interactions we make our own sense of the world. Central to the social interaction theory is the concept of "mediation". The "mediation" is a term o refer to the part played by other significant people in the learners' lives, who enhance their learning by selecting and shaping the learning experiences presented to them. The significant person is known as a mediator. 


\section{TEACHING OBJECTIVES OF MULTI-DimenSIONAL INTERACTION ENGLISH TEACHING}

\section{A. Improving learners' English knowledge and skills}

English knowledge and skills are two important components of college English. They are interrelated with each other to form the basis of comprehensive language competence. Mastery English knowledge and English skills come from practice. The multi-dimensional interaction English teaching is based on the principle of practice and combine knowledge-teaching and skill-cultivating together. Learners use necessary materials to learn phonetic, vocabulary, grammar, topics and communication. A variety of interactive activities are held to strengthen the knowledge. Learners are provided with chances to put what they have learnt into practice.

\section{B. Promoting learners' autonomous learning}

Autonomous learning can be defined as an ability to take charge of their own learning. Learners do not completely rely on teachers and are responsible for setting goals, adopting appropriate strategies, monitoring and evaluating learning process, and using effective resources in a constructive learning process. Promoting learners' autonomous learning is beneficial for improving classroom teaching efficiency. It is also beneficial for learners' future study. The multi-dimensional interaction English teaching pays more attention to cultivating learners' abilities of autonomous. The mode encourages learners to make plans before learning, monitor or adjust the process and the plans during the learning, and check the results after learning.

\section{Developing learners' cooperative learning}

Cooperative learning means that students have a clear division of responsibility in order to complete the common tasks of the group. In cooperative learning, teachers assign learning tasks and control the teaching process. In the classroom, in order to make teachers and students have more effective communication, the teacher divides the students into several groups, and lets the student accomplish the tasks under the guidance of teacher. Cooperative learning provides opportunities for students to cultivate their teamwork spirit and consciousness, develop their cooperative capability, and emphasize cooperative motivation and personal responsibility.

\section{REALIZING CONDITIONS OF THE MULTi-DimenSIONAL INTERACTION ENGLISH TEACHING}

\section{A. Graded English teaching}

Graded English teaching is to teach in accordance with the individual differences of the learners' competence, style, motivation and English proficiency. Different levels of learners arrange different teaching goals, teaching methods, assignment and evaluation methods. The ultimate aim of graded English teaching is to allow all learners to make greater progress in language learning.

Graded English teaching overcomes the disadvantages of traditional English teaching and creates favorable conditions for the implementation of the multi-dimensional interaction English teaching. First, the graded English teaching recognizes the individual differences to ensure the interactive activities to be carried out. Second, learners are grouped into different levels according to their individual differences. Different levels can receive comprehensible input which encourages learners to actively take part in all kinds of activities.

\section{B. The application of multi-media technology into English teaching}

With the development of modern science and technology, the multi-media has been introduced into the field of teaching. The "Requirements" in 2007 pointes out English teaching should use advanced information technology to design computer-based or web-based courses which will provide learners with good language learning environment and conditions. The multi-media combines sound and graphics together and provides a variety of learning materials. It also makes the teaching vivid, authentic and interesting. Learners are attracted to be involved in teaching activities. Meanwhile, the multi-media has a powerful reciprocal functions which can realize the interaction between learners and computer, learners and learners, learners and teachers, learners and teaching materials. The interaction can be one to one, or one to many, or many to many.

\section{TEACHING STRATEGIES OF THE MULTI-DIMENSIONAL INTERACTION ENGLISH TEACHING}

\section{A. Creating teaching situation}

Constructivism stresses on the teaching situation. The teaching situation must be beneficial to the construction of knowledge. While designing course, teachers should take teaching situation into consideration. With the help of teaching situation, in the class, students can be motivated greatly which may lead to the active and automatic construction of knowledge. In order to instruct the students to construct their own knowledge, teachers should try their best to provide a positive learning environment. The teachers should make full use of various facilities to create the teaching situation, such as pictures, movie, slide, computer, role-play, description, background information, questions, story and games.

\section{B. Collaborative learning}

Constructivism holds the views collaborative learning happens consistently through learning process and plays a significant role in accounting and analyzing learning data, presenting and verifying the assumptions, evaluating learning results as well as constructing knowledge. The interaction between learners plays a vital role in understanding leaning content. Learners discuss and communicate with each other under the teacher's arrangement and guide, and then they set up the learning group, become the members of it, and negotiate with others. In this process, the ideas and wisdom of every participant, including the teacher and learners, can be shared within the whole group. That means the whole learning group completes and acquires the content of knowledge altogether rather than only one or some of the members do it independently.

\section{Teaching evaluation}

Evaluation is a key component in college English teaching. A comprehensive, objective, scientific and accurate evaluation system is of vital importance to the achievement of the course 
goal. The teachers should make good use of a lot of information provided by assessment to adjust teaching process to promote the interaction of classroom. The evaluation should follow the principle of "diversity". That is to say, the content and the subject of evaluation should be diverse. The evaluation contents include not only language knowledge and language skills, but also learning process. The evaluation should be conducted by as many people as possible, including learner himself, peers, teachers and school administrators.

\section{CONCLUSION}

The multi-dimensional interaction English teaching is a new teaching model, of which the research is the inevitable result in a new social and historical condition. The fast development of social economy requires all learners to attach greater importance to basic language skills which cover listening, speaking, reading, writing and translating, and to gain the comprehensive ability of using English language. Therefore, it has fundamental significance to change teaching idea, improve traditional classroom teaching pattern and make bold attempts to adopt the multi-dimensional English teaching, and it's also advocated to foster and improve the learners' ability to use their own learning methods and strategies as well as their lifelong learning ability.

\section{REFERENCES}

[1] College English Curriculum Requirements. Beijing: The Ministry of Education, 2007.

[2] Vygotsky, L. 1986. Thought and Language [M]. London: The MIT Press. 